\title{
BMJ
}

\section{Cost effectiveness of self monitoring of blood glucose in patients with non-insulin treated type 2 diabetes: economic evaluation of data from the DiGEM trial}

\author{
Judit Simon, senior researcher, ${ }^{1}$ Alastair Gray, professor, ${ }^{1}$ Philip Clarke, senior international research \\ fellow, ${ }^{2}$ Alisha Wade, resident, ${ }^{3}$ Andrew Neil, professor, ${ }^{4}$ Andrew Farmer, lecturer, ${ }^{5}$ on behalf of the \\ Diabetes Glycaemic Education and Monitoring Trial Group
}

\section{${ }^{1}$ Health Economics Research Centre, Department of Public Health, University of Oxford, Oxford OX3 7LF \\ ${ }^{2}$ School of Public Health, University of Sydney, Australia \\ ${ }^{3}$ Johns Hopkins School of Medicine, Baltimore, MD, USA \\ ${ }^{4}$ Division of Public Health and Primary Health Care, University of Oxford}

${ }^{5}$ Department of Primary Health Care, University of Oxford

Correspondence to: I Simon judit.simon@dphpc.ox.ac.uk

doi:10.1136/bmj.39526.674873.BE

\section{ABSTRACT}

Objective To assess the cost effectiveness of self monitoring of blood glucose alone or with additional training in incorporating the results into self care, in addition to standardised usual care for patients with noninsulin treated type 2 diabetes.

Design Incremental cost utility analysis from a healthcare perspective. Data on resource use from the randomised controlled diabetes glycaemic education and monitoring (DiGEM) trial covered 12 months before baseline and 12 months of trial follow-up. Quality of life was measured at baseline and 12 months using the EuroQol EQ-5D questionnaire.

Setting Primary care in the United Kingdom.

Participants 453 patients with non-insulin treated type 2 diabetes.

Interventions Standardised usual care (control) compared with additional self monitoring of blood glucose alone (less intensive self monitoring) or with training in self interpretation of the results (more intensive self monitoring).

Main outcome measures Quality adjusted life years and healthcare costs (sterling in 2005-6 prices).

Results The average costs of intervention were $£ 89(€ 113$; \$179) for standardised usual care, $£ 181$ for less intensive self monitoring, and $£ 173$ for more intensive self monitoring, showing an additional cost per patient of $£ 92$ (95\% confidence interval $£ 80$ to $£ 103$ ) in the less intensive group and $£ 84$ ( $£ 73$ to $£ 96$ ) in the more intensive group. No other significant cost difference was detected between the groups. An initial negative impact of self monitoring on quality of life occurred, averaging -0.027 (95\% confidence interval-0.069 to 0.015 ) for the less intensive self monitoring group and $-0.075(-0.119$ to -0.031) for the more intensive group.

Conclusions Self monitoring of blood glucose with or without additional training in incorporating the results into self care was associated with higher costs and lower quality of life in patients with non-insulin treated type 2 diabetes. In light of this, and no clinically significant differences in other outcomes, self monitoring of blood glucose is unlikely to be cost effective in addition to standardised usual care.

Trial registration Current Controlled Trials ISRCTN47464659.

\section{INTRODUCTION}

In the United Kingdom, as elsewhere in the world, evidence shows an increased prevalence of type 2 diabetes. The global prevalence of diabetes has reached 5\%, with type 2 diabetes contributing 85 95\% of all cases. ${ }^{1}$ A recent UK study on trends in numbers of diagnosed cases showed a more than 50\% increase between 1991 and $2001 .^{2}$ In 2004, the number of people with diabetes in the UK was almost 1.8 million ( $>3 \%$ prevalence), of whom over 1.5 million had type 2 diabetes. ${ }^{1} \mathrm{~A}$ further one million people may have undiagnosed type 2 diabetes. ${ }^{1}$ With the increasing demand for better management of type 2 diabetes, attention has focused on the potential benefits of self monitoring of blood glucose. Despite inconclusive clinical evidence of its effect in non-insulin treated diabetes, ${ }^{3-5}$ self monitoring has been widely promoted in clinical practice. ${ }^{67}$

Recently, self monitoring of blood glucose has been shown to be the largest single component of management costs associated with implementing more intensive blood glucose control in the $\mathrm{UK},{ }^{8}$ with total costs of providing test strips increasing from $£ 85 \mathrm{~m}(€ 108 \mathrm{~m}$; $\$ 171 \mathrm{~m})$ to $£ 118 \mathrm{~m}$ between 2001 and $2003 .{ }^{9}$ Self monitoring of blood glucose also represents a large component of management costs in other countries. ${ }^{10}$

Improvements in haemoglobin $\mathrm{A}_{1 \mathrm{c}}$ levels are associated with reduced rates of long term complications from diabetes. Although these improvements may lead to gains in quality adjusted life expectancy and generate savings within the healthcare system, self monitoring has opportunity costs, as the funds allocated could potentially be used to finance other aspects of the management of non-insulin treated type 2 diabetes. It is therefore important to establish whether self monitoring represents a cost effective use of resources. We carried out an economic evaluation of 
self monitoring of blood glucose using patient level data on outcome and resource use from the recent randomised controlled diabetes glycaemic education and monitoring (DiGEM) trial. ${ }^{11}$

\section{METHODS}

Our economic analysis on self monitoring of blood glucose in non-insulin treated type 2 diabetes used data from the diabetes glycaemic education and monitoring trial, which has been described in detail elsewhere. ${ }^{11}$ The trial was an open, randomised, three arm, parallel group study of 453 patients with non-insulin treated type 2 diabetes recruited from $48 \mathrm{UK}$ general practices. Briefly, consenting people with type 2 diabetes who had haemoglobin $\mathrm{A}_{1 \mathrm{c}}$ levels of $6.2 \%$ or more and who were not using self monitoring more than once a week were allocated to one of three groups: standardised usual care (control group, $n=152$ ), use of a blood glucose meter with advice for participants to contact their doctor for interpretation of results (less intensive self monitoring group, $\mathrm{n}=150$ ), and use of a blood glucose meter with training in self interpretation and application of the results to diet, physical activity, and drug adherence (more intensive self monitoring group, $\mathrm{n}=151$ ).

At 12 months the differences in haemoglobin $\mathrm{A}_{1 \mathrm{c}}$ levels between the three groups (adjusted for baseline level) were not significant $(\mathrm{P}=0.12)$. The difference in unadjusted mean change in haemoglobin $\mathrm{A}_{1 \mathrm{c}}$ level from baseline to 12 months between the control group and less intensive self monitoring group was $-0.14 \%$ $(95 \%$ confidence interval $-0.35 \%$ to $0.07 \%)$ and between the control group and more intensive self monitoring group was $-0.17 \%(-0.37 \%$ to $0.03 \%)$. Self monitoring had no significantly different impact on glycaemic control when comparing subgroups of people defined by duration of therapy, diabetes related complications, and health related quality of life using the EuroQoL EQ-5D score. Patients allocated to less intensive self monitoring were more likely to persist with using the meter than those allocated to more intensive self monitoring. Ninety nine $(67 \%)$ of those receiving the less intensive intervention and 79 (52\%) of those receiving the more intensive intervention continued to use the meter at least twice a week for the 12 months of the study. ${ }^{11}$

We carried out an incremental cost utility analysis for both self monitoring groups, with difference in costs and in effects calculated in relation to standardised usual care. The study perspective was that of the healthcare purchaser, hence we included only direct costs to the health service. To capture changes in life expectancy and quality of life in one measure we adopted the quality adjusted life year (QALY) as the effectiveness measure. ${ }^{12}$

\section{Data collection}

We collected data on use of healthcare resources for 12 months before study baseline at the recruitment visit and during the trial at follow-up times of three months, six months, nine months, and 12 months. Information was obtained on the frequency of self monitoring, number and average duration of visits to a nurse, daily doses of drugs taken regularly, and the variable of "other healthcare resource use," including primary care (general practitioner and nurse consultations), hospital care (visits to an accident and emergency department, outpatient care, day hospital care, and inpatient care), auxiliary health care (services of a podiatrist, optician, or dietitian), and private health care. These data were collected by means of patients' blood glucose monitoring diaries, notes compiled by nurses, and specific health service use questionnaires, supplemented when necessary by information from patients' medical records. We recorded the duration of consultations with a nurse and we adjusted the average duration in each group to exclude strictly trial related activities, such as trial administration and blood taking.

We included all 453 patients in the base case analysis. For missing information on self monitoring of blood glucose and drug use we carried forward the last known value. We calculated data missing for any reason other than loss to follow-up in the categories for other resource use in Stata 9 by imputation, which was conditional on randomisation group, age, sex, duration of diabetes, and comorbidity. ${ }^{13}$ Our imputation of missing data on length of contacts with nurses was based on the adjusted values and was conditional on type of contact and randomisation group.

\section{Costs}

We calculated costs by multiplying the volume of resource use in each category by the associated UK national level unit cost in 2005-6 prices (table 1). Average costs were estimated in each arm of the study for the 12 months before baseline and the 12 months of follow-up in the trial. We then categorised each item for resource use as part of the cost of the intervention (including nurse intervention and self monitoring of blood glucose), the cost of drugs, or the cost of other healthcare resource use (including primary care, hospital care, and auxiliary health care; table 1). We calculated the mean costs of the intervention and drugs across all patients in each arm of the study. To account for patients lost to follow-up we adjusted the mean costs of other healthcare use for censoring. ${ }^{22}$ Differences in costs between the groups during the 12 months of the trial were adjusted for variations in the costs that occurred during the 12 months before baseline.

\section{Effects}

We estimated the impact of the interventions on quality of life using the EuroQol EQ-5D at baseline and at 12 months. ${ }^{23}$ The distribution of EQ-5D responses across the different levels of each dimension was calculated for complete cases, and we used a $t$ test to compare changes in the distribution between baseline and 12 months between the groups. Mean utility values were derived from EQ-5D responses using the UK tariff. ${ }^{23}$ In the base case analysis we replaced missing values by conditional multiple imputation in Stata $9 .{ }^{13}$ We assumed changes in mean utility values between 
baseline and 12 month follow-up to be straight line transitions. To estimate QALYs gained during the study period we weighted survival times within the trial by the average change in quality of life between baseline and 12 months for each patient. ${ }^{12}$

\section{Analysis}

We undertook a within trial economic analysis, with total healthcare costs and QALYs gained per patient calculated for the 12 months of the trial period in each of the three groups. All analyses were carried out on an intention to treat basis using Excel (version 2003) and Stata 9. We report results as means with standard deviations or standard errors or as mean differences with $95 \%$ confidence intervals. We used sensitivity analyses to examine the effects of imputing missing data and of observed deaths on the main results. We have also included an analysis with an extrapolation of

\begin{tabular}{|c|c|c|}
\hline Unit & $\operatorname{Cost}(£)^{\star}$ & Source \\
\hline \multicolumn{3}{|l|}{ Intervention } \\
\hline Nurse per hour of client contact & 26 & Curtis and Netten $2006^{14}$ \\
\hline Meter & 17.5 & BMA $2006^{15}$ \\
\hline Lancets (100) & 3.4 & BMA $2006^{15}$ \\
\hline Test strips (50) & 17.5 & BMA $2006^{15}$ \\
\hline \multicolumn{3}{|l|}{ Drugs } \\
\hline Oral drugs per prescription & See source & $\begin{array}{l}\text { Department of Health: prescription cost } \\
\text { analysis } 2005^{16}\end{array}$ \\
\hline Insulin per unit & See source & BMA $2006^{15}$ \\
\hline Dispensing fee & $1.54 \dagger$ & Department of Health $2007^{17}$ \\
\hline \multicolumn{3}{|l|}{ Other health care } \\
\hline \multicolumn{3}{|l|}{ Primary care (per surgery visit): } \\
\hline Doctor & 21 & Curtis and Netten $2006^{14}$ \\
\hline Nurse & 8 & Curtis and Netten $2006^{14}$ \\
\hline \multicolumn{3}{|l|}{ Primary care (per home visit): } \\
\hline Doctor & 60 & Curtis and Netten $2006^{14}$ \\
\hline Nurse & 11 & Curtis and Netten $2006^{14}$ \\
\hline \multicolumn{3}{|l|}{ Hospital care (per episode): } \\
\hline Emergency care & $85 \dagger$ & NHS $2007^{18}$ \\
\hline Outpatient care & $96 \dagger$ & Netten and Curtis $2002^{19}$ \\
\hline Day hospital care & $100 \dagger$ & Netten and Curtis $2002^{19}$ \\
\hline \multicolumn{3}{|l|}{ Hospital care (per day): } \\
\hline Inpatient: medical & $269+$ & NHS $2007^{18}$ \\
\hline Inpatient: surgical & $496 \dagger$ & NHS $2007^{18}$ \\
\hline Inpatient: other & $288 \dagger$ & NHS $2007^{18}$ \\
\hline \multicolumn{3}{|l|}{ Auxiliary health care (per session): } \\
\hline Dietitian & 35 & $\begin{array}{l}\text { Department of Health: NHS reference costs } \\
2005-6^{20}\end{array}$ \\
\hline Optician & 18.39 & $\begin{array}{c}\text { Department of Health: review body on } \\
\text { doctors' and dentists' remuneration } 2004^{21}\end{array}$ \\
\hline NHS podiatrist & 31 & $\begin{array}{l}\text { Department of Health: NHS reference costs } \\
2005-6^{20}\end{array}$ \\
\hline Private podiatrist & 50 & $\begin{array}{c}\text { Department of Health: NHS reference costs } \\
2005-6^{20}\end{array}$ \\
\hline Private or allied healthcare professional & $49 \ddagger$ & Relevant agencies \\
\hline \multicolumn{3}{|c|}{$\begin{array}{l}£ 1.00(€ 1.28 ; \$ 1.98) \text {. } \\
\text { *Costs in } 2005-6 . \\
\text { †Inflated to } 2005-6 \text { prices from published cost using Department of Health's pay and price inflation indices. } \\
\ddagger \text { Average of unit costs. }\end{array}$} \\
\hline
\end{tabular}

the results to long term outcomes in an appendix, available at www.herc.ox.ac.uk/downloads.

\section{RESULTS}

The main results are presented here. Additional information to the economic analysis can be found in supplementary tables A-C at www.herc.ox.ac.uk/ downloads.

\section{Costs}

Tables 2 and 3 summarise the results of the cost analysis. The cost of monitoring in both self monitoring groups at 12 months was similar (£96 in less intensive group $v £ 89$ in more intensive group). Nurse time spent on standardised patient care was significantly greater in both self monitoring groups compared with the control group (see table A at www.herc.ox.ac.uk/downloads). The additional cost per patient over one year (including $10 \%$ opportunity cost for non-attended visits), however, was minor: $£ 6$ (95\% confidence interval $£ 1$ to $£ 11)$ in the less intensive self monitoring group and $£ 5$ ( $£ 0$ to $£ 10)$ in the more intensive self monitoring group. The differences in overall costs for intervention were statistically significant: $£ 92$ ( $£ 80$ to $£ 103$ ) between the less intensive self monitoring group and control group and $£ 84$ ( $£ 73$ to $£ 96$ ) between the more intensive self monitoring group and control group (table 2).

Compared with baseline a substantial increase in overall drug costs ( $£ 70$ to $£ 98$ ) was evident in all three groups. Although there was some indication that more patients started using insulin in the more intensive self monitoring and less intensive self monitoring groups than in the control group (five, four, and one patients, respectively), no significant differences were found between the groups in the overall cost of diabetes drugs (table 2).

For the variable of other healthcare costs, nine patients $(2 \%)$ had at least one item missing for the 12 months before baseline and 76 patients $(17 \%)$ had incomplete data over the 12 months of follow-up (see table B at www.herc.ox.ac.uk/downloads). Table 3 presents the results of the base case analysis for the other healthcare costs. A non-significant increase occurred in the variable of other healthcare costs between the period before baseline and follow-up, averaging about $£ 100-£ 150$ per patient in each group, which was mainly attributable to additional admissions to hospital. During the 12 months before baseline the total mean healthcare costs per patient, including drugs, intervention costs, and other healthcare costs, averaged $£ 1042$ for standardised usual care, $£ 1048$ for less intensive self monitoring, and $£ 1145$ for more intensive self monitoring. The costs increased by about $£ 300$ - $£ 400$ over the trial period to $£ 1371, £ 1434$, and $£ 1482$, respectively. No statistically significant differences were found between the groups.

In summary, only the costs of the intervention differed significantly between the control group and the two self monitoring groups. All other changes in costs between the groups during the 12 months of 
Table 2 | Mean (standard deviation) costs $\dagger(£)$ of intervention and drugs and cost differences (95\% confidence intervals) per patient with non-insulin treated type 2 diabetes receiving standardised usual care, less intensive self monitoring of blood glucose, or more intensive self monitoring of blood glucose

\begin{tabular}{|c|c|c|c|c|c|c|c|c|c|c|c|}
\hline & \multicolumn{3}{|c|}{$\begin{array}{l}\text { Standardised usual care group } \\
\qquad(\mathrm{n}=152)\end{array}$} & \multicolumn{3}{|c|}{$\begin{array}{l}\text { Less intensive self monitoring } \\
\text { group }(n=150)\end{array}$} & \multicolumn{3}{|c|}{$\begin{array}{l}\text { More intensive self monitoring } \\
\text { group }(n=151)\end{array}$} & \multicolumn{2}{|c|}{ Difference } \\
\hline & $\begin{array}{c}12 \\
\text { months } \\
\text { before } \\
\text { baseline }\end{array}$ & $\begin{array}{c}12 \\
\text { months } \\
\text { trial } \\
\text { follow-up }\end{array}$ & Change & $\begin{array}{c}12 \\
\text { months } \\
\text { before } \\
\text { baseline }\end{array}$ & $\begin{array}{c}12 \\
\text { months } \\
\text { trial } \\
\text { follow-up }\end{array}$ & Change & $\begin{array}{c}12 \\
\text { months } \\
\text { before } \\
\text { baseline }\end{array}$ & $\begin{array}{c}12 \\
\text { months } \\
\text { trial } \\
\text { follow-up }\end{array}$ & Change & $\begin{array}{c}\text { Less intensive } \\
\text { group } v \\
\text { standardised usual } \\
\text { care }\end{array}$ & $\begin{array}{c}\text { More intensive } \\
\text { group } v \\
\text { standardised usual } \\
\text { care }\end{array}$ \\
\hline $\begin{array}{l}\text { Interven- } \\
\text { tion: }\end{array}$ & - & $89(27)$ & $\begin{array}{c}89 \text { (85 to } \\
93)\end{array}$ & - & $181(49)$ & $\begin{array}{l}181(173 \\
\text { to } 189)\end{array}$ & - & $173(68)$ & $\begin{array}{l}173(162 \\
\text { to } 184)\end{array}$ & $92^{\star}(80$ to 103$)$ & $84^{*}$ (73 to 96$)$ \\
\hline $\begin{array}{c}\text { Self } \\
\text { monitoring }\end{array}$ & - & $10(16)$ & $\begin{array}{c}10(8 \text { to } \\
13)\end{array}$ & - & $96(37)$ & $\begin{array}{c}96 \text { (90 to } \\
102)\end{array}$ & - & 89 (48) & $\begin{array}{c}89 \text { ( } 82 \text { to } \\
97)\end{array}$ & $86^{*}$ (78 to 94$)$ & $79^{\star}(71$ to 87$)$ \\
\hline $\begin{array}{l}\text { Nurse } \\
\text { visits }\end{array}$ & - & 79 (21) & $\begin{array}{c}79(75 \text { to } \\
82)\end{array}$ & - & $85(20)$ & $\begin{array}{c}85 \text { (81 to } \\
88)\end{array}$ & - & $84(26)$ & $\begin{array}{c}84 \text { (80 to } \\
88)\end{array}$ & $6^{*}(1$ to 11$)$ & $5^{\star}(0$ to 10$)$ \\
\hline Drugs: & 444 (278) & 534 (309) & $\begin{array}{l}90^{\star}(66 \text { to } \\
114)\end{array}$ & $480(311)$ & $578(342)$ & $\begin{array}{c}98^{\star}(73 \text { to } \\
123)\end{array}$ & $452(302)$ & $522(317)$ & $\begin{array}{c}70^{*}(47 \text { to } \\
93)\end{array}$ & $9.4(-24$ to 43$)$ & $-20(-53$ to 14$)$ \\
\hline $\begin{array}{l}\text { Diabetes } \\
\text { drugs }\end{array}$ & 98 (151) & $124(163)$ & $\begin{array}{c}26^{*}(12 \text { to } \\
39)\end{array}$ & $120(178)$ & 144 (191) & $\begin{array}{l}25^{\star}(10 \text { to } \\
39)\end{array}$ & $113(173)$ & $123(170)$ & $\begin{array}{c}10(-3 \text { to } \\
23)\end{array}$ & 1 (-18 to 20$)$ & $-14(-33$ to 5$)$ \\
\hline Insulin & 0 & $0.3(4.0)$ & $\begin{array}{l}0.3(-0.3 \\
\text { to } 1.0)\end{array}$ & 0 & $2.5(20.7)$ & $\begin{array}{l}2.5(-0.8 \\
\text { to } 5.9)\end{array}$ & 0 & $4.8(33.7)$ & $\begin{array}{l}4.8(-0.6 \\
\text { to } 10.2)\end{array}$ & $2.2(-3.0$ to 7.4$)$ & $4.5(-0.7$ to 9.7$)$ \\
\hline $\begin{array}{l}\text { Other } \\
\text { drugs }\end{array}$ & $346(222)$ & $410(240)$ & $\begin{array}{c}64^{*}(46 \text { to } \\
83)\end{array}$ & $360(241)$ & $431(279)$ & $\begin{array}{l}71^{*}(49 \text { to } \\
93)\end{array}$ & $339(253)$ & 394 (264) & $\begin{array}{l}55^{*}(35 \text { to } \\
75)\end{array}$ & $7(-21$ to 35$)$ & $-9(-37$ to 19$)$ \\
\hline
\end{tabular}

$£ 1.00(€ 1.28 ; \$ 1.98)$.

${ }^{*} \mathrm{P}<0.05$.

†Costs in 2005-6.

follow-up compared with the 12 months before baseline were similar.

\section{Effects}

The control group showed no significant change in mean utility per patient during the trial. By contrast, patients in both self monitoring groups showed reductions in quality of life, which reached statistical significance for the more intensive self monitoring group. The negative impact of self monitoring resulted in significantly lower quality of life in the more intensive self monitoring group than in the control group (difference $-0.072,95 \%$ confidence interval -0.127 to -0.017 ; table 4$)$.

The EQ-5D questionnaire was fully completed by 313 patients $(69 \%)$, both at baseline and at the 12 month follow-up. Analysis of the distribution of responses across the different levels of each dimension indicated that worsening of patients' quality of life in the self monitoring groups was likely owing to significant increases in the levels of anxiety and depression between baseline and the 12 month follow-up compared with standardised usual care (see table $\mathrm{C}$ at www. herc.ox.ac.uk/downloads).

\section{Sensitivity analysis}

Exploratory analyses for the within trial evaluation included assessing the effect of missing data imputation and the imbalance between the groups in the number of deaths. Changes in quality of life in the self monitoring groups on the basis of complete cases showed similar negative trends to the base case analysis: $-0.037(95 \%$ confidence interval -0.080 to 0.005$)$ for the less intensive self monitoring group and $-0.056(-0.099$ to -0.013$)$ for the more intensive self monitoring group. The variable of other healthcare costs based on available cases only also remained similar to those in the base case analysis (see table B at www.herc.ox.ac. uk/downloads). QALYs gained during the trial were not affected significantly in any group when people who died during the trial were excluded from the analysis (table 5).

\section{DISCUSSION}

In this economic evaluation, self monitoring of blood glucose was significantly more expensive than standardised usual care for non-insulin treated type 2 diabetes. Although the mean lengths of visits to a nurse were longer, the average intervention cost was lower in the more intensive self monitoring group than in the less intensive self monitoring group ( $£ 84$ and $£ 92$, respectively) owing to the higher losses to follow-up in the more intensive self monitoring group. Furthermore, the analysis showed an initial negative impact of self monitoring on quality of life. As the calculation of a formal incremental cost effectiveness ratio is only meaningful when the intervention is more costly and more effective than the comparator, we do not report ratios. Overall, the analysis implies that neither type of self monitoring is likely to be cost effective if added to standardised usual care.

The intervention costs did not include the costs of initial nurse training as the average per patient cost of the non-trial related elements was minor and the training would be part of routine education. None of the other healthcare costs were significantly different between groups. The higher costs of visits to a primary care surgery for the more intensive self monitoring group than for standardised usual care may relate to the observed changes in health status between the groups, with a need to seek further support or advice, or may be a chance finding. 
Table $3 \mid$ Mean (standard error) other and total healthcare costs $\dagger(£)$ and cost differences( $95 \%$ confidence intervals) per patient with non-insulin treated type 2 diabetes receiving standardised usual care, less intensive self monitoring of blood glucose, or more intensive self monitoring of blood glucose

\begin{tabular}{|c|c|c|c|c|c|c|c|c|c|c|c|}
\hline & \multicolumn{3}{|c|}{$\begin{array}{l}\text { Standardised usual care group } \\
\qquad(\mathrm{n}=152)\end{array}$} & \multicolumn{3}{|c|}{$\begin{array}{l}\text { Less intensive self monitoring } \\
\text { group }(n=150)\end{array}$} & \multicolumn{3}{|c|}{$\begin{array}{l}\text { More intensive self monitoring } \\
\text { group }(n=151)\end{array}$} & \multicolumn{2}{|c|}{ Difference } \\
\hline & $\begin{array}{c}12 \\
\text { months } \\
\text { before } \\
\text { baseline }\end{array}$ & $\begin{array}{c}12 \\
\text { months } \\
\text { trial } \\
\text { follow-up }\end{array}$ & Change & $\begin{array}{c}12 \\
\text { months } \\
\text { before } \\
\text { baseline }\end{array}$ & $\begin{array}{c}12 \\
\text { months } \\
\text { trial } \\
\text { follow-up }\end{array}$ & Change & $\begin{array}{c}12 \\
\text { months } \\
\text { before } \\
\text { baseline }\end{array}$ & $\begin{array}{c}12 \\
\text { months } \\
\text { trial } \\
\text { follow-up }\end{array}$ & Change & $\begin{array}{c}\text { Less intensive } \\
\text { group v } \\
\text { standardised usual } \\
\text { care }\end{array}$ & $\begin{array}{c}\text { More intensive } \\
\text { group v } \\
\text { standardised usual } \\
\text { care }\end{array}$ \\
\hline $\begin{array}{l}\text { Other } \\
\text { health care }\end{array}$ & $596(66)$ & 747 (130) & $\begin{array}{l}151(-77 \\
\text { to } 431)\end{array}$ & $567(74)$ & $676(77)$ & $\begin{array}{c}109(-93 \\
\text { to } 297)\end{array}$ & $693(120)$ & $786(145)$ & $\begin{array}{c}93(-173 \\
\text { to } 347)\end{array}$ & $-41(-396$ to 257$)$ & $-57(-447$ to 288$)$ \\
\hline \multicolumn{12}{|l|}{$\begin{array}{l}\text { Primary } \\
\text { care: }\end{array}$} \\
\hline $\begin{array}{l}\text { Doctor } \\
\text { surgery visit }\end{array}$ & $111(7)$ & $100(7)$ & $\begin{array}{l}-11(-25 \\
\text { to } 3)\end{array}$ & $110(7)$ & $90(6)$ & $\begin{array}{l}-20 *(-36 \\
\text { to }-5)\end{array}$ & $89(5)$ & $93(6)$ & $\begin{array}{c}3(-9 \text { to } \\
16)\end{array}$ & $-9(-32$ to 11$)$ & $14(-5$ to 34$)$ \\
\hline $\begin{array}{c}\text { Doctor } \\
\text { home visit }\end{array}$ & $8(3)$ & $9(3)$ & $2(-5$ to 9$)$ & $8(2)$ & $8(3)$ & $0(-5$ to 6$)$ & $5(2)$ & $5(2)$ & 0 (-4 to 5$)$ & -1 (-11 to 8$)$ & $-2(-10$ to 7$)$ \\
\hline $\begin{array}{c}\text { Nurse } \\
\text { surgery visit } \\
\end{array}$ & $33(3)$ & $35(2)$ & 1 ( -5 to 6$)$ & $36(3)$ & $30(2)$ & $\begin{array}{l}-6(-15 \text { to } \\
0)\end{array}$ & $28(2)$ & $32(3)$ & $\begin{array}{c}3(-3 \text { to } \\
11)\end{array}$ & -7 (-17 to 2$)$ & $2(-6$ to 12$)$ \\
\hline $\begin{array}{c}\text { Nurse } \\
\text { home visit }\end{array}$ & $0.4(0.3)$ & $1.9(1.2)$ & $\begin{array}{c}1.5(-0.4 \\
\text { to } 4.4)\end{array}$ & $0.8(0.4)$ & $0.5(0.3)$ & $\begin{array}{l}-0.3(-1.3 \\
\text { to } 0.5)\end{array}$ & $3.2(1.9)$ & $1.1(0.7)$ & $\begin{array}{c}-2.1(-6 \text { to } \\
1)\end{array}$ & $-1.8(-4.8$ to 0.2$)$ & $-3.6(-8.3$ to 0.7$)$ \\
\hline \multicolumn{12}{|l|}{$\begin{array}{l}\text { Hospital } \\
\text { care: }\end{array}$} \\
\hline $\begin{array}{l}\text { Emergency } \\
\text { department }\end{array}$ & $10(3)$ & $12(3)$ & $2(-5$ to 9$)$ & $11(2)$ & $9(2)$ & $-3(-9$ to 4$)$ & $16(3)$ & $14(3)$ & $\begin{array}{c}-3(-11 \text { to } \\
6)\end{array}$ & $-5(-14$ to 4$)$ & $-5(-17$ to 7$)$ \\
\hline Outpatient & 133 (19) & $140(18)$ & $\begin{array}{c}7(-35 \text { to } \\
54)\end{array}$ & $125(16)$ & $163(29)$ & $\begin{array}{l}37(-12 \text { to } \\
102)\end{array}$ & $132(18)$ & $161(25)$ & $\begin{array}{c}29(-24 \text { to } \\
87)\end{array}$ & $30(-35$ to 102$)$ & 23 (-47 to 93$)$ \\
\hline $\begin{array}{c}\text { Day } \\
\text { hospital }\end{array}$ & $9(2)$ & $9(3)$ & $-1(-8$ to 7$)$ & $11(3)$ & $13(4)$ & $\begin{array}{c}3(-6 \text { to } \\
12)\end{array}$ & $5(2)$ & $9(3)$ & $\begin{array}{c}4(-3 \text { to } \\
10)\end{array}$ & $4(-9$ to 16$)$ & $5(-6$ to 14$)$ \\
\hline Inpatient & $172(54)$ & $327(121)$ & $\begin{array}{l}155(-55 \\
\text { to } 410)\end{array}$ & $143(66)$ & $267(67)$ & $\begin{array}{c}124(-61 \\
\text { to } 304)\end{array}$ & 309 (111) & 383 (137) & $\begin{array}{l}74(-172 \\
\text { to } 314)\end{array}$ & $-30(-385$ to 245$)$ & $-81(-449$ to 237$)$ \\
\hline \multicolumn{12}{|l|}{$\begin{array}{l}\text { Auxiliary } \\
\text { health care: }\end{array}$} \\
\hline Dietitian & $5(1)$ & $4(1)$ & -1 (-4 to 2$)$ & $5(1)$ & $3(1)$ & $-2(-5$ to 2$)$ & $9(3)$ & $4(1)$ & $\begin{array}{c}-5^{*}(-11 \text { to } \\
-0)\end{array}$ & -1 (-6 to 3$)$ & -4 (-11 to 2$)$ \\
\hline Optician & $17(1)$ & $19(1)$ & $2(-1$ to 4$)$ & $18(1)$ & $18(1)$ & 0 (-2 to 2$)$ & $17(1)$ & $18(1)$ & $1(-1$ to 4$)$ & $-2(-5$ to 2$)$ & $-1(-4$ to 3$)$ \\
\hline $\begin{array}{c}\text { NHS } \\
\text { podiatrist }\end{array}$ & $34(4)$ & $36(5)$ & $\begin{array}{c}2(-8 \text { to } \\
13)\end{array}$ & $44(5)$ & $42(4)$ & $\begin{array}{c}-2(-12 \text { to } \\
6)\end{array}$ & $44(7)$ & $36(5)$ & $\begin{array}{c}-8(-18 \text { to } \\
0)\end{array}$ & $-5(-19$ to 8$)$ & $-10(-25$ to 4$)$ \\
\hline $\begin{array}{r}\text { Private } \\
\text { podiatrist }\end{array}$ & $43(11)$ & $28(7)$ & $\begin{array}{c}-16^{*}(-34 \\
\text { to }-1)\end{array}$ & $29(8)$ & $21(6)$ & $\begin{array}{c}-8(-22 \text { to } \\
5)\end{array}$ & $26(8)$ & $16(5)$ & $\begin{array}{c}-10 *(-20 \\
\text { to }-2)\end{array}$ & $7(-14$ to 30$)$ & $6(-12$ to 25$)$ \\
\hline $\begin{array}{c}\text { Private } \\
\text { health care }\end{array}$ & $19(6)$ & $25(10)$ & $\begin{array}{c}7(-8 \text { to } \\
22)\end{array}$ & $27(7)$ & $14(5)$ & $\begin{array}{c}-13(-27 \\
\text { to } 1)\end{array}$ & $10(3)$ & $15(6)$ & $\begin{array}{c}5(-3 \text { to } \\
16)\end{array}$ & -20 (-40 to 1$)$ & $-1(-19$ to 16$)$ \\
\hline $\begin{array}{l}\text { Total health } \\
\text { careł }\end{array}$ & $1042(70)$ & $\begin{array}{l}1371 \\
(136)\end{array}$ & $\begin{array}{c}329 *(103 \\
\text { to } 625)\end{array}$ & $1048(82)$ & $1434(84)$ & $\begin{array}{c}387^{*}(188 \\
\text { to } 573)\end{array}$ & $\begin{array}{l}1145 \\
(127)\end{array}$ & $\begin{array}{l}1482 \\
(150)\end{array}$ & $\begin{array}{c}337^{\star}(77 \\
\text { to } 588)\end{array}$ & $58(-305$ to 349$)$ & $8(-381$ to 354$)$ \\
\hline
\end{tabular}

Strengths and limitations of the study

This study is a prospectively designed economic evaluation of information collected on all relevant items of healthcare resource use and quality of life in a randomised controlled trial. The base case analysis used the full imputed dataset but we also did available and complete case analyses on costs and effects, respectively. We adjusted the incremental costs and outcomes for baseline variations between the groups and we used sensitivity analysis to assess the effect of uncertainty surrounding some aspects of the costs and effects.

The estimates of costs and effects reported here are averages for the routine recommendation to use self monitoring across reasonably well controlled patients with non-insulin treated type 2 diabetes. These results may not reflect the costs and benefits in other specific groups, or where usual care has not been standardised to current recommended levels. A further potential limitation of the results is that although the EuroQol EQ-5D is a widely applied generic instrument for measuring quality of life, it may not capture all aspects of quality of life changes for people with type 2 diabetes. $^{24}$

Strengths and limitations in relation to other studies One previous modelling study using aggregated data from a meta-analysis of randomised trials estimated the cost effectiveness of self monitoring to be between $£ 4500$ and $£ 15515$ per QALY gained. ${ }^{25}$ The metaanalysis concluded that the level of clinical evidence available to date showing that self monitoring could 
Table $4 \mid$ Mean (standard error) utility values and utility differences ( $95 \%$ confidence intervals) per patient with non-insulin treated type 2 diabetes receiving standardised usual care, less intensive self monitoring ofblood glucose, or more intensive self monitoring of blood glucose

\begin{tabular}{|c|c|c|c|c|c|c|}
\hline \multirow[b]{2}{*}{ Intervention } & \multirow[b]{2}{*}{ No } & \multicolumn{3}{|c|}{ Utility } & \multicolumn{2}{|c|}{ Difference } \\
\hline & & Baseline & $\begin{array}{l}12 \text { month } \\
\text { follow-up }\end{array}$ & Change & $\begin{array}{l}\text { Less intensive group } \\
v \text { standardised usual } \\
\text { care }\end{array}$ & $\begin{array}{c}\text { More intensive group } \\
v \text { standardised usual } \\
\text { care }\end{array}$ \\
\hline $\begin{array}{l}\text { Standardised usual } \\
\text { care group }\end{array}$ & 152 & $0.799(0.023)$ & $0.798(0.034)$ & $\begin{array}{c}-0.001(-0.060 \text { to } \\
0.059)\end{array}$ & - & - \\
\hline $\begin{array}{l}\text { Less intensive self } \\
\text { monitoring group }\end{array}$ & 150 & $0.781(0.022)$ & $0.755(0.024)$ & $\begin{array}{c}-0.027(-0.069 \text { to } \\
0.015)\end{array}$ & $\begin{array}{c}-0.029(-0.084 \text { to } \\
0.025)\end{array}$ & $\begin{array}{c}-0.072(-0.127 \text { to } \\
-0.017)^{\star}\end{array}$ \\
\hline $\begin{array}{l}\text { More intensive self } \\
\text { monitoring group }\end{array}$ & 151 & $0.807(0.024)$ & $0.733(0.024)$ & $\begin{array}{c}-0.075(-0.119 \text { to } \\
-0.031)^{\star}\end{array}$ & - & - \\
\hline
\end{tabular}

improve haemoglobin $\mathrm{A}_{1 \mathrm{c}}$ levels was only moderate. Problems identified with trials in that analysis included low rates of follow-up, use of per protocol rather than intention to treat analyses, and cointervention with both education and self monitoring compared with usual care. ${ }^{5}$

\section{Implications for clinicians and policymakers}

The results of this analysis, and the previously reported lack of convincing evidence for an impact on haemoglobin $\mathrm{A}_{1 \mathrm{c}}$ levels, ${ }^{11}$ indicate that less intensive self monitoring or more intensive self monitoring of blood glucose are unlikely to have significant lifetime health benefits or to be cost effective in addition to standardised usual care. This study therefore provides no convincing evidence for routinely recommending self monitoring to patients with non-insulin treated type 2 diabetes.

It is possible that subgroups of patients exist for whom self monitoring may be cost effective. These may include, for example, patients who adhere closely to treatment recommendations and who may have been excluded from the trial. Further research may help to characterise such groups.

We compared self monitoring of blood glucose with standardised usual care not usual care on the basis of current practice guidelines for people with type 2 diabetes. The rationale for this comparator has been set out elsewhere ${ }^{26}$ It is possible, however, that in some settings patients are not receiving care to the standards of current practice guidelines. Provision of care in accordance with current recommendations should be a priority.

These results are based on a prospective trial over 12 months. Given this time horizon we may not have captured all relevant costs and effects in the analysis. Therefore we also did a secondary analysis predicting the lifetime quality adjusted life expectancy and costs of complications from diabetes by extrapolating main risk factors beyond the trial period using modelling techniques. Details of this secondary analysis can be found in the appendix available at www.herc.ox.ac.uk/ downloads.

\section{Unanswered questions and future research}

This health economic analysis of self monitoring of blood glucose in people with non-insulin treated type 2 diabetes was carried out prospectively alongside a clinical trial. The data on resource use we collected will be of use when modelling estimates of effects of self monitoring from future studies. Questions about the optimum use and frequency of use of self monitoring for people with insulin treated type 1 and type 2 diabetes remain unanswered however. Further studies

Table 5 Mean quality adjusted life years (QALYs) gained and costs ( $£$ ) $\dagger$ over 12 months ( $95 \%$ confidence intervals) per patient with non-insulin treated type 2 diabetes receiving standard usual care, less intensive self monitoring of blood glucose, or more intensive self monitoring of blood glucose

\begin{tabular}{|c|c|c|c|c|c|}
\hline \multirow[b]{2}{*}{ Variables } & \multirow[b]{2}{*}{$\begin{array}{l}\text { Standardised usual } \\
\text { care }\end{array}$} & \multirow[b]{2}{*}{$\begin{array}{l}\text { Less intensive self } \\
\text { monitoring group }\end{array}$} & \multirow[b]{2}{*}{$\begin{array}{l}\text { More intensive self } \\
\text { monitoring group }\end{array}$} & \multicolumn{2}{|c|}{ Difference } \\
\hline & & & & $\begin{array}{c}\text { Less intensive group } v \\
\text { standardised usual } \\
\text { care }\end{array}$ & $\begin{array}{l}\text { More intensive group } \\
v \text { standardised usual } \\
\text { care }\end{array}$ \\
\hline \multicolumn{6}{|l|}{ Main results: } \\
\hline QALYs gained & $\begin{array}{c}0.000(-0.013 \text { to } \\
0.014)\end{array}$ & $\begin{array}{c}-0.008(-0.023 \text { to } \\
0.007)\end{array}$ & $\begin{array}{c}-0.035(-0.050 \text { to } \\
-0.020)^{\star}\end{array}$ & $\begin{array}{c}-0.008(-0.029 \text { to } \\
0.012)\end{array}$ & $\begin{array}{c}-0.036(-0.056 \text { to } \\
-0.015)^{\star}\end{array}$ \\
\hline Costs & 89 (85 to 93) & 181 (173 to 189$)$ & 173 (162 to 184$)$ & $92(80 \text { to } 103)^{\star}$ & $84(73 \text { to } 96)^{\star}$ \\
\hline \multicolumn{6}{|l|}{ Deaths excluded: } \\
\hline QALYs gained & $\begin{array}{c}0.002(-0.010 \text { to } \\
0.015)\end{array}$ & $\begin{array}{c}-0.006(-0.021 \text { to } \\
0.009)\end{array}$ & $\begin{array}{c}-0.030(-0.044 \text { to } \\
-0.016)^{\star}\end{array}$ & $\begin{array}{c}-0.008(-0.028 \text { to } \\
0.011)\end{array}$ & $\begin{array}{c}-0.032(-0.052 \text { to } \\
-0.013)^{\star}\end{array}$ \\
\hline Costs & 89 (85 to 93) & 183 (175 to 190$)$ & 174 (163 to 185$)$ & $94(85 \text { to } 102)^{\star}$ & $85(73 \text { to } 97)^{\star}$ \\
\hline \multicolumn{6}{|c|}{$\begin{array}{l}£ 1.00(€ 1.28 ; \$ 1.98) \\
{ }^{\star} \mathrm{P}<0.05 . \\
\text { †Costs in } 2005-6 .\end{array}$} \\
\hline
\end{tabular}




\section{WHAT IS ALREADY KNOWN ON THIS TOPIC}

The clinical effects of blood glucose testing in non-insulin treated type 2 diabetes are unclear

Self monitoring of blood glucose is costly

A previous study suggesting that routine self monitoring could be cost effective for non-insulin treated diabetes was potentially confounded by heterogeneity

\section{WHAT THIS STUDY ADDS}

Self monitoring in non-insulin treated type 2 diabetes is unlikely to be cost effective and should not be recommended for routine use

The additional intervention costs of self monitoring of blood glucose are between $£ 84$ and $£ 92$ per patient over 12 months

Self monitoring has an initial negative impact on quality of life, in part associated with increased reported anxiety

may be needed to determine the cost effectiveness of self monitoring if evidence of effectiveness is found for people with non-insulin treated type 2 diabetes at specific stages of their disease trajectory or with particular characteristics.

We thank the participants in the diabetes glycaemic education and monitoring trial and their general practitioners for support and help. Contributors: $A G, A N$, and $A F$ had the original idea for the economic evaluation. AF and AW managed the trial. IS and AG developed the economic analysis plan and carried out the evaluation. PC contributed to the extrapolation beyond the trial. JS wrote the first draft of the manuscript with AG and AF. All coauthors reviewed and commented on the final manuscript. JS is the guarantor of this paper. Members of the DiGEM Trial Group are as follows-writing committee: JS, AG, PC, AW, AN, and AF; investigators: AF, AG, AN, D French, R Holman, A-L Kinmonth, D Mant, S Ziebland, and P Yudkin; steering committee: N Stott (chair), AF, AN (to 2005), S Sutton, H Tewson, D Chapman, H Hearnshaw, E Goyder (from 2005), P Glasziou (from 2005), M Jiwa (2004 to 2005), and M Gordon (from 2005); intervention development: AW, AF, D French, A-L Kinmonth, and MP Selwood; coordinating centres: (Oxford) AW (to 2005, trial coordinator), JS (health economist), A Craven (trial manager), P Yudkin (trial statistician), and A Fuller (data manager); and (Sheffield) V Walker (local trial administrator); data monitoring committee: C Baigent (chair), J Levy, and K Wheatley; research nurses (Oxford) MP Selwood, H Kirlow, M Chapman, and S Turner; (Sheffield) A Casbolt, K Dobson, A Willert, A Roberts, and H Wood; and central laboratory: K Islam.

Funding: The diabetes glycaemic education and monitoring trial was funded by the UK NHS and the NHS health technology assessment programme. The opinions expressed in this report are not necessarily those of the Department of Health. JS was supported by an NHS research and development research scientist award. AF was supported by an NHS research and development career development award from 2001-5. The Department of Primary Health Care, University of Oxford is a partner in the National Institute for Health Research School of Primary Care Research. Competing interests: AG has been reimbursed by Eli Lily for attending several advisory meetings.

Ethical approval: The diabetes glycaemic education and monitoring study was approved by the Oxfordshire Research Ethics Committee B (002.059).
1 Diabetes UK. Diabetes in the UK 2004. London: Diabetes UK, 2004.

2 Fleming DM, Cross KW, Barley MA. Recent changes in the prevalence of diseases presenting for health care. BrJ Gen Prac 2005; 55:589-95.

3 Coster S, Gulliford MC, Seed PT, Powrie JK, Swaminatham R. Selfmonitoring in type 2 diabetes mellitus: a meta-analysis. Diabet Med 2000;17:755-61.

4 Sarol JN Jr, Nicodemus NA Jr, Tan KM, Grava MB. Self-monitoring of blood glucose as part of a multi-component therapy among noninsulin requiring type 2 diabetes patients: a meta-analysis (1966 2004). Curr Med Res Opin 2005;21:173-84.

5 Welschen LMC, Bloemendal E, Nijpels G, DekkerJM, Heine RJ, Stalman $W A B$, et al. Self-monitoring of blood glucose in patients with type 2 diabetes who are not using insulin: a systematic review. Diabetes Care 2005;28:1510-7.

6 Gerich JE. Clinicians can help their patients control postprandial hyperglycemia as a means of reducing cardiovascular risk. Diabetes Educ 2006;32:513-22.

7 Owens DR, Barnett AH, Pickup J, Kerr D, Bushby P, Hicks D, et al. Blood glucose self-monitoring in type 1 and type 2 diabetes: reaching a multi-disciplinary consensus. Diabetes Primary Care 2004;6:398-402.

8 Gray A, Clarke P, Farmer A, Holman R, on behalf of the United Kingdom Prospective Diabetes Study (UKPDS) Group. Implementing intensive control of blood glucose concentration and blood pressure in type 2 diabetes in England: cost analysis (UKPDS 63). BMJ 2002;325:860-5.

9 Farmer AJ, Neil A. Variations in glucose self-monitoring during oral hypoglycaemic therapy in primary care [letter]. Diabet Med 2005;22:511-2.

10 Davidson MB. Counterpoint: self-monitoring of blood glucose in type 2 diabetic patients not receiving insulin: a waste of money. Diabetes Care 2005;28:1531-3.

11 Farmer A, Wade A, GoyderE, Yudkin P, French D, Craven A, et al. Impact of self-monitoring of blood glucose in the management of patients with non-insulin treated diabetes: open parallel group randomised trial. BMJ 2007;335:132-9.

12 Drummond MF, O'Brien B, Stoddart GL, Torrance GW. Methods for the economic evaluation of health care programmes. Oxford: Oxford University Press, 1997.

13 Royston P. Multiple imputation of missing values: update of ice. Stata J 2005;5:527-36.

14 Curtis L, Netten A. Costs of health and social care 2006. Kent: Personal Social Services Research Unit, 2006.

15 British Medical Association and Royal Pharmaceutical Society of Great Britain. British National Formulary (BNF) 52. London: BMA, RPSGB, 2006.

16 Prescription cost analysis 2005 [computer program]. www.ic.nhs.uk/ pubs/prescostanalysis2005 (accessed 3 Apr 2007).

17 Department of Health. Departmental report: the government's expenditure plans 2006-07 to 2008-09. London: TSO, 2007.

18 National Health Service. Annual financial returns of NHS trusts 20032004. Leeds: NHS, 2007.

19 Netten A, Curtis L. Unit costs of health and social care 2002. Kent: Personal Social Services Research Unit, 2002.

20 Department of Health. NHS reference costs 2005/06. London: DoH, 2007.

21 Department of Health. Review body of doctors' and dentists' renumeration: review for 2004. London: DoH, 2004.

22 Bang J, Tsiatis AA. Estimating medical costs with censored data. Biometrika 2000;87:329-43.

23 Dolan P, Gudex C, Kind P, Williams A. A social tarifffor EuroQol: results from a UK population survey. York: Centre for Health Economics, University of York, 1995.

24 Rabin R, de Charro F. EQ-5D: a measure of health status from the EuroQol Group. Ann Med 2001;33:337-43.

25 Palmer AJ, Dinneen S, Gavin JR, Gary A, Herman WH, Karter AJ. Costutility analysis in a UK setting of self-monitoring of blood glucose in patients with type 2 diabetes. Curr Med Res Opin 2006;22:861-72.

26 Farmer A, Wade A, French DP, Goyder E, Kinmonth AL, Neil A. The DiGEM trial protocol-a randomised controlled trial to determine the effect on glycaemic control of different strategies of blood glucose self-monitoring in people with type 2 diabetes [ISRCTN47464659]. BMC Fam Pract 2005;6:25.

Accepted: 14 March 2008 